\section{Transparência e Controle}

\author{
Transparency and Control
}

Renato Sérgio de Lima ${ }^{1}$

O artigo de Minayo e Adorno retoma, na defesa da redefinição dos conceitos de risco e segurança para se pensar a missão policial, um debate acerca dos modelos de organização do Estado e de suas instituições encarregadas de garantir direitos e ordem pública. Para tanto, o texto parte de uma pertinente contextualização histórica sobre as instituições policiais e demonstra que as características que deram origem às polícias no Ocidente mantêm-se basicamente as mesmas nos últimos três séculos; com os mesmos dilemas sobre como garantir lei e ordem (repressão versus prevenção, contenção versus participação).

A partir desse ponto de partida, os autores irão destacar como os conceitos de risco e de (in)segurança operam na origem positivados pelas sociedades capitalistas e de que forma isso vai conformando os padrões operacionais e de treinamento das corporações policiais, bem como a vida e o comportamento dos, no caso brasileiro, quase 700 mil homens e mulheres que se dedicam à esta profissão.

Pela sua argumentação, os conceitos de risco e segurança precisariam ser ampliados para contemplar novas configurações impostas pela contemporaneidade e pelos desafios do desenvolvimento (crime organizado, precariedade das condições de vida e salário). O impacto que as questões de arquitetura institucional provocam na vida dos policiais seria, portanto, um indicador de que, para além das questões de ordem política, se faz necessário pensar na mudança do modelo de organização da segurança pública no Brasil.

De modo geral, tendo a concordar com a hipótese dos autores e reconheço no artigo um grande esforço intelectual de (re)valorização de algumas dimensões que muitas vezes ficam invisíveis ao macrodebate sobre reformas institucionais.

$\mathrm{Na}$ minha perspectiva, os conceitos de risco e (in)segurança estariam inscritos, tal como a produção de dados estatísticos sobre crimes e criminosos, como produtos da racionalidade contemporânea do Estado e, por isso, inevitáveis de serem contemplados na modelagem da arquitetura institucional das corporações, mas o artigo de Minayo e Adorno vão confirmar que tais conceitos somente podem ser operados se acoplados à discussão da modernização tecnológica do po- der e com um olhar holístico que abarque o indivíduo: o policial.

E é aqui que, a meu ver, o artigo poderia ter avançado um pouco mais e se aprofundado as discussões sobre governança e accountability. Nessa linha, retomo reflexão feita em $2005^{1}$, inspirada em Norberto Bobbio, para quem se faz necessário observar as condições com as quais os mecanismos institucionais operam e se não se tornaram por demais opacas aos controles democráticos. Em Bobbio tal necessidade nasce de uma grande dicotomia entre público e privado, donde "o segredo é a essência do poder e a democracia é o poder em público". Por trás dessa aparente oposição reside o desafio de garantir que o Estado seja conduzido por autoridades visíveis e, com isso, controláveis quanto aos seus objetivos e decisões.

Em outras palavras, numa democracia, risco e (in)segurança seriam conceitos operados sob influência de dois requisitos fundamentais, quais sejam: transparência e controle. É por meio desses dois últimos requisitos que, com base em critérios públicos, decisões sobre padrões táticos e operacionais deixam de ser território exclusivo de um saber altamente especializado e estariam submetidas ao crivo das esferas política e estratégica da administração do Estado. E, na inobservância ou inexistência de tais requisitos, cumpre-nos pensar numa agenda em que risco e segurança passam a ser variáveis de planejamento e governança.

Como já foi dito, uma polícia pouco transparente e sem controle tende a se fechar num jogo corporativo de autopreservação e a desconsiderar as condições sociopolíticas e históricas das sociedades que as mantêm. Nessa brecha, riscos deixam de ser calculados e (in)segurança passa a ser apenas uma referência moral para justificar desigualdades, a manutenção do ideal de defesa do Estado e, sobretudo, agendas criminalizantes dos conflitos sociais que marcam as sociedades capitalistas, em especial as de desenvolvimento recente como a brasileira e de outros países latino-americanos.

Caberia, por conseguinte, aproveitar a contextualização histórica para analisar as permanências autoritárias e a forma pela qual ordem e

${ }^{1}$ Fórum Brasileiro de Segurança Pública. renato.lima@forumseguranca.org.br 
desordem são trabalhadas. Essa seria uma pista para compreendermos muitos dos movimentos que obstaculizam avanços mais significativos nas mudanças diagnosticadas como necessárias por Minayo e Adorno, mas sempre adiadas. E, na tentativa de contribuir para essa discussão, reproduzo abaixo, com pequenas modificações, texto que serviu de justificativa para a proposição de Colóquio "A construção da ordem: conflitos, participação e segurança pública no Brasil”, realizado no 35․ Encontro da ANPOCS, em 2010.

Ao falar de segurança pública e crime no Brasil, constatamos a evolução do modo como o Estado foi absorvendo as demandas por ordem e de que modo elas vão se configurando e/ou moldando aos modelos de desenvolvimento do país. Da pública tranquilidade, tal como era chamada pelo Código de Processo Penal da década de 30 do século XIX, à ordem pública, presente em nossa Constituição de 1988, percebemos uma enorme dificuldade de definição conceitual daquilo que pode ser considerado o substrato pelo qual as instituições do Estado brasileiro vão organizar suas estruturas e basear seu funcionamento, sobretudo as polícias e o sistema de justiça criminal.

Estudo do Fórum Brasileiro de Segurança Pública, de 2010, identificou que, na legislação e na jurisprudência brasileiras, os conceitos de segurança e ordem públicas são circulares e pouco claros, cabendo à doutrina jurídica orientar as decisões dos operadores do sistema de justiça criminal. A pesquisa também verifica que, na construção do significado de ordem pública, essa mesma doutrina não está, por sua vez, informada pelos princípios da Constituição de 1988 e baseia-se, em muito, em pressupostos da ideologia da segurança nacional, pré-1988. Com isso, abre-se a possibilidade para diferentes usos do sistema de justiça criminal brasileiro.

Corroboram-se assim as linhas de pesquisas que investigam como é construída, de um lado, a sujeição criminal a partir de determinadas características de parcela da população e, por outro lado, a submissão dos interesses da sociedade aos interesses do Estado, que por sua vez são influenciados por uma parcela da elite que consegue mobilizar e pautar as agendas públicas de acordo com seus interesses privados.

Mais recentemente, a organização das polícias e do sistema de justiça criminal ganha os contornos moldados na Escola Superior de Guerra (ESG) e cuja peça fundamental se estruturava a partir da conexão entre o binômio segurança nacional e desenvolvimento econômico. Em suas análises da formação da ideologia desenvolvimentista, poderíamos dizer modernizante, que buscava aprimorar a subordinação da sociedade ao Estado, Otávio Ianni² destaca a ocorrência, entre 1949 e 1964, do amadurecimento de uma metamorfose na ideologia militar. Para ele, nesse período a doutrina da Defesa Nacional, propugnada com força pela ESG, foi substituída e/ou absorvida, pós 1968, pela doutrina da segurança nacional. O principal viés doutrinário dessa ideologia é fazer crer que em torno do desenvolvimento econômico circulam conflitos e disputas pela hegemonia política da nação tanto por concorrentes externos como por interesses de opositores internos, exigindo a subordinação e o controle absoluto da sociedade.

Segurança não é um fim em si, mas articulase e depende da economia e da capacidade de intervenção do Estado. A partir de então segurança e desenvolvimento passam a ter um caráter de mútua causalidade. Ou seja, o que poderíamos chamar de modelo da ESG é tão somente uma estratégia de desenvolvimento baseada numa profunda subordinação da sociedade ao Estado. Nesse processo, as instituições encarregadas de manter a ordem pública, em especial as polícias, são subsumidas por tal ideologia.

$\mathrm{Na}$ medida em que, nesse processo, vislumbra-se a institucionalidade da ordem e o Estado aparece como força, materializado pela instituição policial, percebe-se que o projeto de desenvolvimento brasileiro circunscreveu-se apenas a partir da dimensão econômica. O desenvolvimento social, reforçado pela Constituição de 1988, é lembrado apenas como distribuição de renda, sem inclusão de demais direitos de cidadania. A CF de $1988^{3}$ tão somente deslocou, em seu artigo 144, o conceito de segurança nacional e o substituiu pelo de segurança pública, sem, no entanto, avançar na remodelagem do sistema de justiça criminal e do aparato institucional encarregado de garantir Lei e Ordem no país.

A situação histórica da segurança pública inaugura uma importante inflexão a partir de meados dos anos 1990, quando alguns poucos governos estaduais começam um movimento que visava repensar o papel da atuação das policiais. O foco principal dessa discussão era fazer "integrar" as ações das diferentes polícias e fazêlas assumir que sua atuação deveria ser voltada para a defesa da cidadania e não mais do Estado.

Se tal inflexão não foi forte o suficiente para alterar o contexto sociojurídico brasileiro, ela parece induzir, não sem contradições e resistências, mudanças de repertório e formulação de 
novos enunciados políticos, nos quais mecanismos de accountability e de governança sejam compreendidos enquanto instrumentos de eficiência democrática, vinculando o respeito aos Direitos Humanos às práticas operacionais das polícias na prevenção da violência e no enfrentamento do crime [e aqui teríamos a conexão com o debate do artigo de Minayo e Adorno, ou seja, a chave para que no desenho de políticas de segurança pública e de procedimentos operacionais das polícias os riscos e o sentimento de (in)segurança sejam levados em consideração].

\section{Referências}

1. Lima RS. Contando crimes e criminosos em São Paulo: uma sociologia das estatísticas produzidas e utilizadas entre 1871 e 2000 [tese]. São Paulo: Universidade de São Paulo; 2005.

2. Ianni O. Pensamento Social no Brasil. São Paulo: Anpocs, Edusc; 2004.

3. Brasil. Constituição da República Federativa do Brasil de 1988. Diário Oficial da União 1988; out 6. 